\title{
THE THAI GARDEN
}

\section{Khaisang Sukhavadhana ${ }^{1}$}

Gardens which have long been in existence obviously have specific characteristics determined by their environments. These characteristics include climate and local flora as well as religious beliefs and social and cultural conditions distinct to each country. The world's famous gardens, be they Chinese, Japanese, Indian (during the Mogul Dynasty), Spanish and French gardens, all have interesting features by which they are known. As for the "Thai Garden," despite the fact that it does not enjoy the same degree of fame accorded to the gardens aforementioned, it can also boast a long history, evolving in tandem with Thai architecture. With its own amazing characteristics, the Thai-style garden is therefore a subject worthy of study and research.

The characteristics of a traditional Thai garden may be summarized as follows.

a. Plants found in a Thai garden are not only the flowering type. Fruit trees are also planted since Thais have long perceived their importance as an economic crop.

b. Historically, only a monarch or his deputy could own a large or spacious garden. These gardens were usually located outside the boundaries of the palace proper

\footnotetext{
${ }^{1}$ Professor Emeritus, Chulalongkorn University
}

or beyond the city walls and were usually natural gardens. They were guarded by caretakers and designated as off-limits to the general public.

c. Gardens used to landscape permanent architectural structures mostly comprised dwarfed trees and potted plants. These gardens could usually be found in the palaces, royal residences and important temples. As for miniature mountains known as "Khao Mor" or rockeries, these were found only in palaces, royal residences and important temples as well, since it was believed that gardens of this particular type should not be featured in a commoners place of abode except if it were a person of high rank and status, or within temple grounds. Another type of man-made mountain, "Khao Mor", created ceremonially according to Brahmin religious rites, was also constructed exclusively. for royal ceremonies held on the royal palace grounds.

d. Herbal gardens--when extant would only be found in temples. Monks knowledgeable in traditional medicine would tend to these gardens from which herbs used as ingredients for different remedies were derived. During the Ayutthaya period when Thais were engaged in continuous warfare with the Burmese, or sometimes in internal conflicts, different types of "Waan" believed to promote immortality were cultivated among the different groups of 
learned men. The popularity of the "Waan" can be traced as far back as the early Ayutthaya period.

e. Aquatic gardens intentionally created were extremely rare. Most of them started as ponds, pools, ditches or canals for freshwater storage with different types of lotus and water lilies added later on. These water sources thus evolved into aquatic gardens.

f. In days of yore, people from all levels of society, from the nobility to commoners, rich or poor, lived in houses made entirely of wood. The size of these houses would be determined by the owner's social status as well as their wealth. Nevertheless, most of these houses shared common architectural features, especially the spacious front verandah. It was on this verandah that potted plants of various types would be placed - some in the shaded area under the roof and others in the open.

g. Historically speaking there do not appear to have been any gardens dedicated specifically as a public park, aside from King Ramkamhaeng's palm grove where the faithful would congregated for Buddhist sermons and Bueng Phra Ram (Bueng Chi Khan) a vacant lot within the precincts of Ayutthaya City. In traditional contexts, public parks were not essential to the lifestyle of the main population, which was still sparse and not concentrated in one particular area. If they desired open spaces for relaxation or recreation, the fields and pastures beyond the city's boundaries could serve those purposes more than adequately.

\section{Thai Gardens in the Sukhothai Period.}

The stone inscription of King Ramkamhaeng gives indications that fruit orchards were popular with the people of Sukhothai. The cultivation of a variety of fruits is one evidence that agriculture was the main occupation (followed by trade and commerce). On the other hand, flowers were also cultivated for aesthetic pleasure. Historical and archaeological evidence seems to indicate that there were few flower gardens to be found within the royal palace grounds as a diversion for the king.

It is difficult, however, to determine the exact characteristics of these gardens since there is no evidence in existence (even the throne halls and royal palaces dating back to that period have not survived to give any indication as to their architectural style). Nevertheless, since there are several religious monuments made of laterite, sand stone and terracotta which are still standing, we can thus surmise that the gardens in the palace and royal temple grounds probably made use of those same building materials to a certain extent. The flora in these gardens were probably a mixture of flowering plants and fruit trees. While the style of landscaping most likely conformed to the taste and preference of the monarch or according to what the architect of such a palace, hall or temple would deem appropriate or beautiful.

In those times, the Thai people, who adhered strictly to the tenets of Buddhism, firmly believed that sweet smelling flowers and other fragrant offerings of worship were 
ideal as a medium to convey the profound faith and strong desires of the person to the Lord Buddha. For this reason, flowering trees and shrubs were usually of the fragrant type. It is probable that the seedlings of these fragrant flowering trees were brought from the forests. In the temples, whether they belonged to the village sects or forest sects, large trees were possibly planted to give shade as well as for decorative purposes. The advantage of planting tall trees is that they are enduring and are easy to care for. The monks could easily find sufficient time from their studies of the Dhamma scriptures to sweep fallen leaves or petals. One large tree that was popular was the bo-tree, significant in its symbolism, according to Buddhist history, as the tree under which the Lord Buddha sat when he succeeded in subduing Mara (the legendary figure of Evil) as well as under which he atttained enlightenment. It has been noted in the inscriptions of King Mahathammaraja Lithai that bo-tree seedlings from Anurajpuri in Sri Lanka were transported to Sukhothai and planted in the royal monasteries of Sukhothai.

Areas in the city that were waterways, such as the city moat, canals, pools, ponds or reservoirs would be filled with blossoming lotus flowers both of the royal and ordinary type. Such water plants were also essential in maintaining the clarity and cleanliness of the water, making it suitable for daily consumption.

Finally, one should also mention the forests and hills situated outside the city precincts. These areas not only provided respite and relaxation to the monarchs and their loyal subjects but also served as the locale for the sanctuaries of monks belonging to the forest sect, those seeking solitude for prayer and meditation. The lush beauty of large trees were maintained in their natural condition with occasional pruning and trimming, so that the area would remain clean and pleasing to the eye.

\section{Thai Gardens in the Early Ayutthaya Period.}

The author has designated the first three hundred years when Ayutthaya was the seat of power as the Early Ayutthaya Period. Despite the length in time evidence available for research on gardens is extremely scarce. Whatever little information available is found in certain literary texts and the royal chronicles. Thus, a study of the characteristics of gardens of this era inevitably relies heavily on supposition, as is the case for the Sukhothai garden.

According to what is said in the literary texts, gardens in the early Ayutthaya period were mostly natural gardens. However, like the gardens in the palaces at Sukhothai, gardens in the palaces of Ayutthaya were also beautified with flowering plants and fruit trees.

The spacious grounds in the royal palace of the king were usually located outside the palace walls, if not the boundaries of the city. One example being Suan Luang Sob Sawan, to the west of the palace walls. The fictional gardens mentioned in literature are also situated beyond these walls, such as Suan Kwan, the garden of Phra Puen and Phra Paeng, the two heroines in Lilit Phra 
Lo. We know it to be such because "one glides over to ride atop the elephant in the same way we enter the palace gates" but the distance is not so great since "not too long after one reaches the garden gates." Similarly, the Suan Luang gardens of Traitrueng City mentioned in Myth of Tao Saen Pom are also a short distance away from the palace, "when one reaches Suan Luang one is close to approaching the palace."

Because of the spaciousness of the royal gardens it could be assumed that there probably were areas of bodies of water. The ponds were of two types : the first were ponds already in existence in the area designated to be gardens; while the second were ponds that had been dug so that the soil could be used to fill adjacent areas. The sides of some of these ponds were decorated with stone stucco. They were filled with lotus flowers of various types whereas, on the sides, trees and shrubs provided shade and tranquil greenery. Due to the fact that the climate in Thailand makes it hot and humid in the daytime, pavilions were therefore included in these gardens. The rest of the grounds appeared in tune with the natural surroundings.

Another type of royal garden were those surrounding the royal residences used exclusively by the king on his royal sojourns. The landscaping of this type of garden depended mainly on the locale of the palace. These locales were of two types: those situated in the lowlands inundated in the rainy season, with pre-existing ponds; and those situated in valleys at the foot of a mountain with natural flowing streams.
Gardens of this latter type were landscaped in such a way that they altered the natural surroundings as little as possible. These royal gardens were off limits to the public, with caretakers guarding the premises as well.

During the early Ayutthaya period public parks, in the true sense of the word, had yet to come into existence. The largest vacant lot in the city precinct, where people gathered in their leisure, was the Bueng Phra Ram (or Bueng Chi Khan) area. If they so desired, the public could head to the outskirts, beyond the city walls, for their recreational activities.

\section{Gardens during the Reign of King Narai the Great.}

Ayutthaya reached its zenith during the reign of King Narai. It was during this time that Thais came into contact with the West, with more Westerners travelling to the kingdom than at any other given moment in the history of Ayutthaya. Historical archives, both Thai and foreign, are abundant in documentation on this period, even on matters regarding its gardens, compared to the dearth of information on preceding eras. Writings by Westerners such as chronicles, journals and autobiographies provide insightful details on gardens and related matters. For these reasons, the author dedicates the reign of King Narai as an entire period of its own, despite its brevity of 32 years, in this "History of the Thai Garden." Incidentally, in compiling the history of this particular period, the wealth of resources for research and documentation meant that one could 
rely less on assumptions than for the preceding eras.

More information is available on this period to shed more light on gardens or royal grounds within the royal palaces. This is especially so in the case of the royal gardens on the premises of Suthasawan Throne Hall in the royal palace of Lopburi, since Western visitors had documented what they saw in their writings. During that period, it was still a common practice to plant flowering trees and fruit trees alongside each other. Moreover, in the king's royal garden one could also find exotic plants which had been offered as gifts by foreign guests of the royal court. These exotic plants originated from such places as Java, China, the Malayan peninsula and southern India. The royal gardens would feature ponds with lotus flowers blooming in abundance and fish of various types contributing to the decorative nature of their environment. There is also evidence that man-made hills in miniature had also come into existence during this period. These miniature hills or rockeries were an attractive addition to the gardens. The materials used in the landscaping of these grounds comprised different types of rock and brick which were used to pave the pathways, laid around the edges of the ponds or around beds of decorative plants.

A distinctive decorative feature not seen in gardens of previous eras is the fountain found in the compound of the Lopburi royal palace. After European missionaries and engineers laid down a waterworks system and the water pressure was sufficient, fountains were constructed to add aesthetic beauty to those grounds. The gardens in the royal palaces served not only as recreational areas for the king but also as venues for receptions to welcome diplomatic delegations. Large trees with blossoms, some of them fragrant, lined the compounds, or grown in the royal temple grounds, since these were the places spacious enough for them.

Royal gardens in the countryside, such as those in the summer residence outside Lopburi, were mainly natural gardens with similar characteristics to the gardens in the royal residences used by the king on his sojourns during the early Ayutthaya period.

\section{Thai Gardens in the Early Rattanakosin Period.}

The story of the garden in the early Rattanakosin period begins when King Rama I established Bangkok as the kingdom's new capital. During this reign, however, Thailand was still engaged in warfare with Burma and this was still regarded as a period of reconstruction. For these reasons, construction, be that of the city or its palaces, was not carried out with too much meticulousness or with much emphasis on strength and endurance. One must take into consideration constraints in terms of time, manpower and also, finances. Nevertheless, most structures built at the behest of Rama I usually conformed to traditional features from the days when Ayutthaya was the helm. It was the king's desire that foreign countries should be aware that Thailand had resumed to conditions when all was well as they had been in prosperous days of yore. 
For the reasons aforementioned, the gardens in the Grand Palace maintained the features of the gardens of the royal palace of Ayutthaya. By royal command, gardens were featured perpendicular to each other: one named the "suan khwa - the right garden" and the other, the "suan sai - the left garden". In both gardens, trees that bear fruits indigenous to Thailand were planted. Decorative plants, those providing flowers or attractive foliage, were planted in flower pots. A certain type of potted plant considered a staple in these gardens was the bonsai, said to have been popular since the Ayutthaya period. Another essential feature was the Khao Mor or miniature mountain made in those days from sea sponges or coral stone. Because the grounds were spacious, the king also ordered the digging of ponds where numerous types of lotus flowers were planted. One final feature that must be mentioned are the royal residences surrounded by water and pavilions or cool palaces dedicated for the kings private moments of relaxation.

In the ensuing reign, the Grand Palace was expanded southwards at the behest of King Rama II. In the initial stages, because the expanded areas were still vacant, a rose garden was created, by royal command so that the roses could be used for palace purposes. This marked the first time roses were seriously cultivated within the Grand Palace.

King Rama the Second did not order any significant structures be added to the Grand Palace since it was deemed that the buildings created in the previous reign were still sufficient. What he did order was the beautification of the inner courtyards to be used for pleasurable pursuits of recreation and a venue for His Majesty's artistic creation. Some of his favoured courtyards were Suan Sanamchand besides the west Portico of Amarindaravinichai Throne Hall and Suan Ton Chandra adjacent to the Sanam Ratchakij Gate leading to Chakrapadibhiman and Phaisal Taksin Throne Halls.

In 1818 , King Rama II instructed that Suan Khwa, constructed in the reign of his predecessor, undergo improvements to create an atmosphere of joy and delight. The improved version of Suan Khwa became one of the most famous gardens during this reign and stories regarding it practically became major highlights in the history of the Thai garden of the Rattanakosin era. Incidentally, the intention to develop Suan Khwa was not concerned mainly with use for personal pleasure but for other reasons as well. Firstly, to bring dignity to his country, it was his fervent hope that foreign nations could perceive that the Thai kingdom had once again resumed the peace and prosperity it once enjoyed. Secondly, it was his gracious desire to restore Thai artisans' superb artistic creations which had faced significant demise since the fall of Ayutthaya, particularly since His Majesty the King himself was supremely skillful as an artisan. Finally, it was also his wish that Suan Khwa be enjoyed by the members of the inner court, since the female royalty and nobility did not often have the opportunity to experience the life and natural surroundings beyond the confinements of the palace walls. 
Knowledge of bonsai cultivation and Japanese plants is indeed significant. Dating back to the Ayutthaya period, Thai people are said to have enjoyed dwarfed plants. Creating these ornamental plants became a hobby initiated by Buddhist monks in the temples, before the practice spread to the nobility and wealthy families. During the reign of Rama II bonsai cultivation enjoyed immense popularity with none other than His Majesty the King and Crown Prince Pitakmontri showing an avid interest in the delightful hobby. Other members of the royal family, monks, noble men and people of means were also keenly interested. This popularity continued well into the reign of King Rama III who himself considered the cultivation of bonsai ornamentals as his personal hobby.

Another matter of importance concerns gardens on front verandahs and the different varieties of plants cultivated in a traditional Thai house. The author has based suppositions on the nature of the Thai garden on descriptions of the front verandah garden in Khun Chang Khun Phaen, a literary text belonging to the reign of King Rama II. This information is especially pertinent since it has been noted that the episode when Khun Phaen climbs up Khun Chang's abode with its vivid descriptions of the verandah garden is actually a royal composition of King Rama II himself. One realizes, therefore, that the garden on Khun Chang's verandah actually represents a verandah garden in the home of any wealthy person in the early Rattanakosin period. The main feature of this type of garden is that it comprises an array of potted plants. These plants --fruit trees, flowering plants or ornamental foliage--are mostly native to Thailand with only a few of foreign origin since they were still extremely rare in those times. The plants in these collections, specially the flowering plants, were selected not only for their attractive shapes and colours but also with the desire to enjoy the fragrances that would pleasantly fill the air. These potted varieties would be scattered about - some in the open and others beneath the eaves of the house. Ornamental fish were also considerably popular then. Some houses would place glazed stone basins containing water lilies and fish, an added decorative feature to the front verandah. Moreover, if the owner of the house was a bird-lover, an apiary would be included on the porch and birds of different types kept for their colourful plumage or melodious sounds that would resonate the house during the day. As for the planting of trees in the traditional Thai house, some superstitions dictated that certain types of trees should be planted on the compound around the house in the correct directions accorded by the ancestors. Such adherence would bring about prestige and prosperity to all those who dwelled in that residence. Conversely, certain types of trees were also prohibited either from being planted in close proximity to the main house or on the compound altogether. These prohibitions are not exactly ungrounded superstitions but beliefs derived from experience and profound knowledge of the negative points of each particular tree.

During the reign of King Rama III, Chinese art was highly favoured by the king, who himself had engaged in commercial trade with China from the time he still held the 
title of H.R.H. Krom Muen Chesadabodin. It was thus unavoidable that the trend originating with the monarch should proliferate among the nobility and wealthy members of society who adopted a taste and liking for Chinese art and all things Chinese. Such preferences included "gardening according to Chinese traditions," i.e., the proliferation of plants of Chinese origins, dwarfed trees Chinese in style or appearance, the use of Chinese porcelain for pots and jars, the cultivation of plants, water lilies and ornamental fish and the popularity of miniature mountains in pots or tray gardens.

When King Rama III commissioned renovation of the royal chapels such as Wat Phra Chetuphon, Wat Arunratchawararam and Wat Suthat-thepwanaram, his taste for Sino art was demonstrated in the decorations and adornments that were added. Chinese stone statues in all types and sizes were prominent features in the landscaping of these temples, such as Chinese-style pagodas, Chinese pavilions dedicated to the various directions, gateways, lampposts with dragon motif carvings, altars, water lily pots, stone drums with animal designs, and even statues of human beings, usually depicting a character in Chinese opera by the name of "Lan tan," their sizes ranging from the smallest to the largest.

During the process in which Wat Phra Chetuphon underwent major renovations, a Chinese-style garden was added at the behest of His Majesty the King. This garden, known as "Misakawan" or "Mai Tor" garden, is reminiscent of a Chinese garden with a pond, small bridges, Chinese pavilions, artificial mountains made up of rocks piled to resemble a lion or mythical gilen ( a fabulous Chinese four footed creature with a scaly body and a dragon's head) or plants known as "Mai Chai En" planted by the side of the pond. All these features contribute in creating the atmosphere one usually connects with a Chinese Garden--the type belonging to a philosopher or learned person which replicates the natural wilderness with its forests and streams within a specified area. The king intended this garden to be a tranquil corner ideal for individuals seeking a peaceful place to meditate or to contemplate on his studies of the Dhamma.

Aside from adorning Wat Phra Chetuphon with the remarkable statues and artificial mountains aforementioned, the king also saw to it that small garden patches be scattered around the compound. Medicinal herbs and trees were planted in these patches which rendered the temple grounds the largest herbal garden to be found in any Royal Chapel of the early Rattanakosin period.

In 1739 , King Rama III commissioned the construction of the Sattamahasathan in Wat Suthatthepwanaram. It has been noted that stupas are not found in this royal chapel as in other temples. In actual fact the Sattamahasathan can itself be regarded as a stupa, an object of worship and reverence, created out of devout adherence to the Buddhist faith. His Majesty King Rama III envisioned this extraordinary structure to be a place for future generations to remember, as the translation of the name 
"Sattamahasathan" implies the seven objects connected to the Lord Buddha. These objects comprise, Phra Rattana Ballang referring to the seat beneath the bo-tree where the Lord Buddha attained enlightenment, represented in this temple by a bo-tree; Phra Animmischedi, the place where the Lord Buddha was in standing meditation staring at the bo-tree without a blink; Phra Rattanachongkromchedi or the jeweled hall of residence, represented in this temple by a Chinese pavilion with stone engravings : Phra Atchapal Nikoratha or the bunyan tree; Phra Mujalintapreuk or the Chik, a tree in Lecythidaceae family, and Phra Rachayatanapruek or the Ked (Mimusops hexandra).

\section{Bonsai and Japanese Plants}

The art of bonsai has long been a hobby for Thais, dating back to the Ayutthaya period. It was first popular in the temples and then spread to the palaces and homes of the wealthy. It is clear, though, that during the reign of King Rama I the bonsai was used to decorate the throne halls and royal palaces and gardens as well as to landscape the Grand Palace compound.

In the ensuing reign of Rama II, the bonsai enjoyed widespread popularity from the monarch himself to members of the royal family, the clergy, nobility and commoners of means.

The bonsai may be classified as:

1. Mai Khabuan -- plants grown upright for two-or three thirds of their entire height then bent inwards and upwards in whatever fashion, finally so that the ends meet with the topmost part of the main trunk. Mai Khabuan is also known by its other name, "Mai Yod Laem," or "pointed top".

2. Mai Chak -- a plant perpendicular in shape, its branch or branches folding in at an angle. The plant can be a single or double trunk, usually shaped in Chinese fret design affecting a symmetrical look to the branches.

3. Mai Hok Hian -- a plant with its branches pointing down to the ground and emerging up, sometimes entwined around the trunk. Its shape resembles the grace and rhythm of Chinese martial arts.

4. Mai Khen -- a plant with branches pointing in three different directions: one downward, another to the side and the last one upward. The branches should not have too many leaves on them and each of them should face different directions while the top part should be turned back approximating the gestures of a deer glancing backward.

5. Mai Pa Khom -- a plant with a trunk or branches in either a straight or crooked position but with the branches entwined to create a rounded effect. Bonsais of this type are rather short and stout, its circular shape resembling an alms bowl placed upside down with a total of nine or more branches each equally apart from each other.

6. Mai Yee Pun -- a Bonsai which replicates the original Japanese style believed to have been popular since the Ayutthaya era. Dwarfed plants were originally formed 
naturally in Japan. In the country's mountainous terrains certain large trees growing on the crevices of rocks would find it difficult to nourish their roots. Moreover, since they were constantly beaten by strong winds, their growth would be stunted as a result. The Japanese who discovered these plants were attracted to their extraordinary appearance and transferred them to the confinement of flower pots to maintain their dwarfed appearance. The Japanese Bonsai is therefore a tree diminished in size from large, full-sized trees growing naturally. The branches and leaves hardly require any pruning or clipping, or if they do, only the minimal, so as to affect a style as close as possible to its natural appearance.

7. Mai Kam-ma-lo -- a bonsai shaped in a downward spiral, the opposite of Mai Hok Hien, the tip always facing a downward position.

8. Mai Talok -- a bonsai which uses the roots as the trunk. It is crooked in appearance and does not conform to any particular shape. If a root becomes visible and pushes the trunk upward until its trunk or roots can be distinguished, it earns the name "Mai Talok Rak" or "Mai Plaeng Kone."

9. Mai En Chai - a bonsai which does not stand upright, whose shape resembles a tree bending down to the water. Bonsais of this type are usually used to decorate the Khao Mor or artificial mountains, to create a natural appearance. Mai En Chai is usually planted on the hindside of these mountains in a cradle-shaped flower pot.
Aside from classifying bonsais into the types aforementioned, bonsai experts in the past also classified them according to their trunk formations as follows.

1. Mai Ko -- a bonsai with multiple trunks stemming from a common base.

2. Mai Tor -- a bonsai which previously had a large trunk which has been chopped off until only a stump is standing, considerably higher up from the ground.

3. Mai Ton -- a bonsai with a single trunk.

Trees ideal for being dwarfed are those which are tough in texture, not brittle or easily broken. The leaves should be small in size and the branches healthy. The shape should remain consistent and not alter too frequently such as Tako, Khoi, Cha, Makham, Manaotes, Masang, Khao Tok and Mok. $^{2}$ The most popular tree is the Tako

2 Tako - medium-sized perennial tree with a thick bark, black in colour. The Tako comes in two types - Tako Baan (Diospyrus rhodocalyx) with rounded, sometimes slightly oval, leaves. Its fruit is plump, the size of a small mangosteen, astringent though sweet in taste; Tako $\mathrm{Na}$ (Diospyros embryopteris) has large leaves, thick and coarse in texture. Its fruit is larger than that of Tako Baan, very astringent in taste, sometimes called Tako Suan.

Khoi (Streblus asper) - a small sized perennial in the same family as the olive

Cha (Malpighia coccigera) - a tree with thorns on its trunk that can be dwarfed, its leaves small in size, appear rather tattered with pointed ends, yields white blossoms, also known as Cha Pattavia (Battavia Tea). 
(Diospyrus embryopteris), a type of ebony, a tree which endures long years and whose beauty intensifies the older it grows. The Tako has features similar to those of a large tree. Its trunk is black in colour and on it appears aesthetically pleasing knobs or protuberence, while its leaves, which are deep green in hue also appear to have a sheen and do not easily fall from their branches. When dwarfed, the Tako maintains it shape permanently.

The Tako is usually dug up from forest areas such as those around Nakhon Chaisi, Ratchaburi, Suphan Buri and Kanchana Buri. Some of these trees are propagated from seeds such as the Feronia lucida while

Makham (Tamarindus indica) - a middle to large size perennial with sprays of leaves resembling the leaves of the Sanoh; its flowers also bloom in sprays of reddish yellow, its bark is tough in texture.

Manaotes (Triphasiatrifolia) a small-sized tree said to have originated in China, has thorns on its trunk, tiny leaves, bears fruit similar to the Japanese cherry but the skin resembles that of an orange, sweet and spicy in taste.

Masang (Feronia lucida) - a perennial with thorns, leaves similar to those of the wood apple but bears smaller fruit, sour in taste.

Khao Tok (Serissa foetida), a shrub with small oval-shaped leaves that emit a strong smell when rubbed or crushed, bears tiny white blossoms.

Mok (Wrightia religiosa) an ornamental plant with fragrant blossoms clustered in sprays, commonly found in Buddhist temples. others are found in orchards or groves on the outskirts of the city, such as the Streblus asper, Tamarindus indica, Malpighia coccigera and wrightia religiosa, which grows naturally on its own. A person who develops a passion for dwarfed trees should be extremely patient and conscientious in an endeavour that can sometimes take years to complete. He must also be dedicated and willing to work painstakingly to create a dwarfed tree that conforms to conventional dictates such as perfection of shape, symmetry between branches, etc.

\section{Khun Chang's Verandah Garden And Trees Planted in the Tradi- tional Thai House Compound}

A brief survey of the characteristics of Traditional Thai house construction at this point serves to provide basic understanding about the features, functions, and decoration of an important area of the house, the verandah.

In his book on traditions related to construction of a Thai house. Sathienkoses provides the following information about the old-style Thai house.

"... In the old days Thai houses were singlestory, of rectangular shape with floors raised high on timber posts and an open verandah on one side. The Thais were mainly agriculturists whose livelihood depended on water. Therefore, they preferred to build their houses at waterside, close to the rivers, canals or ponds. The raised floors were particularly advantageous during the rainy season when overflowing rivers flooded the banks and house compounds. During dry 
periods, the open area beneath the house served as working space for daily activities such as spinning and weaving. Even in the highlands where people subsisted on field crops the houses were built on raised posts but for a different reason. In those areas the threat to people's wellbeing came from wild beasts that roamed the village and its surrounding forests at night. In the old days when trees were abundant it was relatively easy to build wooden houses. The Thais' preference for a single story house was also related to their belief in the importance of the khwan (soul or life essence). A person's khwan was said to dwell on the top of his head, which was considered the most sacred part of the body. If the head were treated in a disrespectful way, grave misfortunes would befall the person. A single story house helped to prevent undue disturbance to the head ".

Traditional Thai houses are unique in that they can be built almost completely in a single day. Different parts of the house are made beforehand and then assembled on the appointed auspicious day with the help of relatives and neighbours. Construction work starts early in the morning and the major parts of the house are finished by the evening. The verandah and other minor details can be completed on the following day(s).

In the same book Satheinkoses also avers:

"...After a long period of happiness and prosperity in the blessed house. The living quarters might become crowded with the presence of grown-up offspring. Usually, one or two houses were later built along side but further to the front of the original house. Sometimes new houses were built for newlywed daughters. The tradition of building separate houses for married children was in accordance with the old saying of "mee luk phen tao, mee yao phen ruen", meaning children and houses make a family. Additional houses were generally smaller in size, all of which were positioned to face the original house. An open terrace linked these houses. The main house was called Hor Klang (the central house); the house immediately to its front was called Hor Ree; and the one further out to the front was called Hor Kwang because it was situated "against the sun" or lying in the north to south direction. Such a position made Hor Kwang unsuitable for sleeping quarters and was used as a place to receive visitors instead. It was built in the same style as Palai (relaxation quarters attached to the main house); both structures were paneled on three sides with the fourth left open. Only their locations were different; Hor Kwang was usually built at the end of the terrace. If Hor Kwang was built, there was no need for a Palai. With many houses in the group, the connecting terrace became so large that a small open structure could be built in the middle. This structure was referred to as Hor Nang, a sitting pavilion, and was used for relaxation or religious ceremonies. It has an equivalent of Hor Chan or Hor Suadmon (dining and prayer hall) in a temple. Any house in the group with one side left open could become a sitting hall. Another construction was Hor Nok (a birdhouse). A trellis was usually built at the back of the sitting hall to support fragrant or fruit-bearing climbing plants such as khajorn (milkweed), Chinese 
kadang-nga (ilang-ilang), maliwan (climbing jasmine) and laddawan (climber of the family Canvolvulaceae)..".

The above quotation vividly depicts the typical location and features of the terrace. Long strips of lumber, taller than eye level, were used to enclose the terrace and to provide some protection for the residents. Potted plants of fragrant and climbing varieties line the terrace edges. At one corner is situated a large water jar for drinking and bathing. Large bowls for growing water lilies and keeping fish are placed next to the verandah. During the day the terrace provides space for drying clothes, food and medicinal herbs, but at night it is used for family relaxation. How lavishly the terrace is decorated depends on the social status and aesthetic taste of the owner of the house. A rich owner like Khun Chang in the classical story of Khun Chang Khun Phaen, would have been in the position to decorate his terrace exquisitely.

There are a number of beliefs and taboos concerning the planting of trees in the traditional Thai house compound. We may begin with those related to the immediate vicinity of the house first. Thai people placed special importance on the appropriate type of trees and their location in connection to the house. There are eight directional points to be observed in planting the trees. Strict observation of such rules will ensure continuous happiness and prosperity to the residents.

Certain trees should not be planted near the house and others should not be planted anywhere within the compound. They are large perennial trees such as the bo (Ficus religiosa), sai (banyan), yang (Dipterocarpus alatus), tan (Palmyra palm), wa (Java plum or Jambolan), and ngiew (Bombax malabaricum Malvanccae or a red silk cotton tree).

There are five reasons for taboos against these trees. Firstly, all of them are perennials with strong and large trunks that can easily damage or destroy the house when uprooted by a storm. Secondly, these trees attract large birds, some of which are unwelcome - for example, vultures. The presence of this bird in a house is believed to bring bad luck and misfortune to the household. Thirdly, these trees usually grow abundantly in the forest and their products can be readily obtained. Therefore, there is no need for growing them near the house. The land in the house compound can be put to better use by growing trees with economic value. Fourthly, the bo, banyan and Java plum are regarded as sacred because of their religious significance in connection with the Lord Buddha. These "religious trees" belong to the temple grounds. Lastly, certain trees are prohibited for their dangerous or repulsive attributes, which make them not suitable for residential grounds. For example, the ngiew has thorny trunks, the salatdai or a type of spiked cactus usually grows in large clumps, and the samrong has a repugnant smell.

After discussing the topic of large sized perennials in the homes let us now also mention medium and small sized trees which function to bear fruits and are used as ornamental decorations. Small and medium sized perennials frequently grown in the 
yards are mangoes of all types, rose apple, lamut (Manilkara kauki), jackfruit and longan. These trees provide perfect shade on sunny and hot days. Small bamboo beds are also usually placed under some of these trees for people to relax and children to play. Certain types of other trees are also planted so that their leaves, flowers and fruits may be used for cooking like Yor (Morinda citrifolia), Sadao (Melia indica), Makrood (kaffir lime or Citrus hystrix), Manao (lime or Citrus aurantifolia), Mayom (Phyllanthus distichus), and Madan (Garcinia schomburgkiana) etc. These trees are not planted in large numbers, perhaps one or two only per household. Small-size ornamental flowers and leaves, both the ones planted in pots or directly on the ground are Jasmine, Poot (Ervatamia colonaria), Nang Yaem (Cleorodendrum), Prayong (Aglaia odorata), Ngon Kai (cock's comb), Dao Ruang (Marigolds), Ban Yen (gomphrena globosa), Chaba (hibiscus), khem ((Rubiceae), Maak Phu Maak Mia (Gymnosporia stylosa and Cordyline fruiticosa - types of betal plams), varieties of waan (Thai plants in the lily and hemp families, some species used for medicinal purposes and others believed to have magical powers for protection, etc.) Herbacious ornamental plants and shrubs are usually placed next to the stairway leading up to the house or along the pathways, a colourful and pleasing sight. There would also be bushes with flowers blooming in profusion around the main house and along pathways reminiscent of the bushes planted around the compound of Khun Chang's residence which the poet eloquently describes, "planting lush bushes/ so graciously delightful." Another flowering tree, the Ratri, is usually something people refrain from planting on verandahs since its flowers which bloom exclusively during the night have a strong scent, intolerable to some. The Ratri is therefore planted in the ground at a certain distance from the house so that its fragrance is diffused in the air. If the owner of the house happens to be keen on gardening his love of plants will be reflected in the beauty of his healthy garden.

On some of these compounds, a pond may be located not too far from the main house. Shrubs would grow and flourish along the side of these ponds, such as the Lamchiak (Pandamus teclorius) a plant with large flowers and a light fragrance, the Plubplueng (Crinium asiaticum) with white and crimson flowers blooming in clusters, Prik (Asparagus sprengeri) with leaves in sprays, fragrant white flowers and yellow and orange pollen, Toey (Pandanus ordoratissimus) with long, tapering leaves in solid green, Krachab (Thai water chestnut), its roots are black on the outside and white on the inside, sweet and creamy in taste. The ponds will have lotus flowers blooming in radiant beauty. Houses situated on the banks of canals would have cannas with their bright coloured flowers, planted in order to prevent the corrosion of the banks. On these canals one could find aquatic vegetables like Phak Bung (Ipomea aquatica) and Phak Krached (Neptunia oleracea or the water mimosa) grown in clusters around bamboo poles with barriers to keep them in place. These clusters of vegetables are extremely beneficial, aside from being a source of food, it is also a perfect way to attract fish so that they may be trapped or caught for food. At the docks, 
pavilions are built as a place for relaxation. These pavilions usually have trellises so that creepers with sweet smelling flowers could climb up. Some of the popular creepers are Kachorn with yellowish flowers which bloom in sprays. Kachorn blossoms smell like a new crop of rice or Toey leaves. The fragrant flowers and young fruits are edible as a supplementary vegetable. Aside from the Kachorn, there is also the Maliwan with flowers, some strong and others light in fragrance, Chinese Kradang-nga, Thai Kradang-nga (also known by the name of Karawek), Rossukon and Chommanaad, Leb Mue Nang, for example.

A plot next to the kitchen behind the house is usually the area designated as a kitchen garden. It is here that one finds such essential ingredients in Thai cooking as chili peppers, egg plants, ginger, galangal, lemon grass, basil and sweet basil, and if space permits, some tobacco as well. Houses with a spacious compound and sufficient manpower will also grow bananas, sugar cane, mangoes, betal palms and coconut trees - all of which are also economic crops. Whatever is leftover from consumption within the household may be sold. Boundaries within the house usually come in three forms - the first is done by digging a moat around the house, as in the case of Khun Chang where "one arrives at the home of Khun Chang and beholds fortification in the form of a moat around," the second is a fence made of twigs entwined by rattan, usually reserved only for the front fence, while the third comprises bamboo planted to make a hedge, gaps anywhere are filled with barbed wire, in so doing one not only designates the boundaries of one's property but also prevents the beasts of burden from other households from trespassing and loitering inside the property. 